American University Washington College of Law

Digital Commons @ American University Washington College of

Law

Articles in Law Reviews \& Other Academic Journals

Scholarship \& Research

2014

The Protection of Geographical Indications in the Inter-American Convention

Christine Haight Farley

Follow this and additional works at: https://digitalcommons.wcl.american.edu/facsch_lawrev

Part of the Intellectual Property Law Commons, and the International Law Commons 


\title{
The Protection of Geographical Indications in the Inter-American Convention
}

\author{
Christine Haight Farley \\ Professor of Law, American University Washington College of Law, Washington
}

\section{Introduction}

The international community is currently deeply divided, with no agreement in sight, over the appropriate level of protection for geographical indications (Gls). Gls receive extensive protections within the European Union (EU) that go beyond international standards, while the United States is generally opposed to strengthening existing international Gl protections.1 The fundamental conflict between the positions of the European Union and the United States on this protection have come to a head in the negotiations over the Transatlantic Trade and Investment Partnership Agreement. While the president of the EU Parliament has stated that Gls "are one of Europe's greatest assets", 2 the United States believes that stronger GI protections will result in US consumers paying higher prices for food while their options in grocery stores will be diminished. The potential resolution of this disagreement could have enormous global consequences both in terms of paving the way forward for a new multilateral trading system, but also for the coherence of the international system for the protection of Gls.

The conflict over Gls between the European Union and the United States had previously come to a head in the negotiations on the Agreement on Trade Related Aspects of Intellectual Property Rights (TRIPS Agreement). Since that time, the European Union and the United States have been competing to promote their different approaches to the protection of Gls in other countries and regions. This strategy has involved the development of bilateral or plurilateral agreements that contain these two different approaches. $\mathrm{A}$ case in point are the two very different approaches taken in the free trade agreements negotiated with Korea by the United States in 2007 and the European Union in 2011.4

Simply put, the difference in the two approaches is that the European Union prefers sui generis protection for Gls, while the US approach is founded on traditional notions of trademark law. 5 It has been observed that in its bilateral and regional free trade agreements the United States has hardened its trademark approach to the protection of Gls, while the EU approach in its free trade agreements has moved further towards a registration-based system; the EU system involves the establishment of a GI register. These differences have caused commentators to speculate over whether the two systems are now at all compatible.6

\footnotetext{
* I am indebted to American University law student Kristin Lockhart for her superb research assistance. I am also grateful for the helpful comments received at the 2014 International Intellectual Property Law Scholars Roundtable at DePaul University College of Law.

1 Lina Monten, "Geographical Indications of Origin: Should They Be Protected and Why? An Analysis of the Issue from the U.S. and EU Perspectives" (2005) 22 Santa Clara High Tech. L.J. 315 (noting how the members of the World Trade Organization who ultimately enact the laws proposed by the treaties are split between the EU and the "Old World" in favour of enhanced protection of Gls and the US and the "New World" in favour of limited protection, if any).

2 Catherine Saez, "WIPO Design Treaty Fate Left to Assembly, Despite Shift on Technical Assistance" Intellectual Property Watch, March 21, 2013, available at http://www.ip-watch.org/2014/03/21/wipo-design-treaty-fate-left-to-assembly-despite-shift-on-technical-assistance/ [Accessed October 22, 2014] (citing to a letter written by EU Parliament President Martin Schulz to members of the Internet Corporation for Assigned Names and Numbers (ICANN) expressing concern over the misuse of European Gls as domain names).

3 Bernard O'Connor, "The European Union \& the United States: Conflicting Agendas on Geographical Indications-What's Happening in Asia?" (2014) 9 Global Trade \& Customs J. 66.

4 Compare chapter 18 of the US-Korea Free Trade Agreement with chapter 10 of the European Union-Korea Free Trade Agreement.

5 O'Connor, "The European Union \& the United States" (2014) 9 Global Trade \& Customs J. 66.

6 O'Connor, "The European Union \& the United States" (2014) 9 Global Trade \& Customs J. 66 (casting doubt on Korea's implementation and application of both agreements).
} 
While the protection of Gls is certainly a modern-day concern in an era of globalised markets, Gls also have ancient roots. The European history of Gl protection is usually noted, but few have explored the history of Gl protection in the United States.7 Conventional wisdom holds that the United States is a late comer to the protection of Gls, and that its stance has always been to limit protections. However, US law on indications of geographical origin goes back almost 150 years. And surprisingly, the United States played a key role in developing one of the first plurilateral agreements that protected Gls. Given its current stance on Gl protection, it is remarkable that the United States has been bound by an international convention that has ensured strong protection of Gls since February 20, 1929. Since that date, the United States has been a member of the General Inter-American Convention for Trade Mark and Commercial Protection (Inter-American Convention). ${ }_{8}$ What is even more astonishing is that, at the time, the provisions on Gls in the Inter-American Convention were the most developed and strongest protections available in any international agreement.

The inclusion of a fairly extensive chapter on the protection of Gls in the Inter-American Convention is curious as the United States has never been viewed as a major proponent of Gl protection. Contrary to the popular belief that the United States has historically failed to protect Gls, the United States has itself established international protections for Gls. An understanding of this agreement and the particular protections it affords Gls would provide insights into the US position on Gls, which may offer a sturdier basis for international negotiation on their protection. This agreement indicates what should be the minimum standards for the protection of Gls in the United States given that this agreement is still in effect. Moreover, as this agreement sought to merge the US common law of unfair competition with the Latin American registration-based system, it may suggest a way out of the current impasse between the United States and the European Union.

\section{The Inter-American Convention as a milestone in the development of GI protection}

The international protection of Gls is a fairly recent occurrence. Although the Paris Convention first addressed the protection of Gls in 1883 , it is generally acknowledged that that protection was quite limited. It included "indications of source" and "appellations of origin" as protected areas of intellectual property, but it did not define these terms or include any enforcement provisions.9

The Madrid Agreement for the Repression of False or Deceptive Indications of Source of Goods, which was ratified in 1891, extended protection against "deceptive" indications of source in addition to "false" indications. A deceptive indication of source can be the true name of the place from which the good originates, but nevertheless confuses the purchaser with respect to the true origin and quality of the good.10 The Madrid Agreement also prohibits appellations for wine from becoming generic. It only had 17 members in 1929.

Other international agreements containing stronger Gl protections followed the Inter-American Convention. The International Convention on the Use of Appellations of Origin and Denominations of

\footnotetext{
7 Felix Addor and Alexandra Grazioli, "Geographical Indications beyond Wines and Spirits: A Roadmap for a Better Protection for Geographical Indications in the WTO/TRIPS Agreement" (2002) $5 \mathrm{~J}$. World Intell. Prop. 865, 869; Raffi Melkonian, "The History and Future of Geographical Indications in Europe and the United States", available at http://dash.harvard.edu/handle/1/8852204 [Accessed October 22, 2014]; WIPO, "Geographical

Indications: Historical Background, Nature of Rights, Existing Systems for Protection, and Obtaining Effective Protection in Other Countries", January 25, 2001, SCT/6/3; L.S. Tellier, "Unfair Competition in Use of Geographical Tradename by Persons Carrying on Business Elsewhere" (1948) 174 A.L.R. 496.

8 General Inter-American Convention for Trade-mark and Commercial Protection 1929. The convention is referred to as both the Inter-American Convention and the Pan American Convention.

9 Article 1(2) of the Paris Convention states: "The protection of industrial property has as its object patents, utility models, industrial designs, trademarks, service marks, trade names, indications of source or appellation of origin, and the repression of unfair competition." Article 10(i) of the convention requires countries to seize "on importation" or "inside the country" any goods bearing a "direct or indirect use of a false indication of the source of the goods". Article 10bis(3) was not added until 1958.

10 Article 1(1) provides that: "(A)II goods bearing a false or deceptive indication by which one of the countries to which this Agreement applies, or a place situated therein, is directly or indirectly indicated as being the country or place of origin shall be seized on importation into any of the said countries."
}

The Protection of Geographical Indications in the Inter-American Convention 53 (2014) 6 W.I.P.O.J., Issue 1 @ 2014 Thomson Reuters (Professional) UK Limited and Contributors 
Cheeses (Stresa Convention) was not concluded until 1951, and the Lisbon Agreement for the Protection of Appellations of Origin and Their International Registration (Lisbon Agreement) was not concluded until 1958.

Before 1929 domestic law in Europe also did not provide for extensive Gl protection. The first law addressing the false designation of origin on labels was enacted in France in 1905, 11 but appellations of control (AOC) were not established until 1908. Even then, AOC did not address quality or the method of production.12 The first law that resembles what we now understand as French AOC protection was not enacted until 1919.13 It was not until 1935-six years after the Inter-American Convention-that the Institut National des Appellations d'Origine (INAO) was created, ${ }_{14}$ the same year that French law established a special category of AOC for wine and spirits. Champagne was not granted an AOC until the following year.

\section{Resurrecting the forgotten Treaty}

This abbreviated timeline of the protection of Gls both internationally and in France demonstrates that there were not many legal protections that preceded the Inter-American Convention. The Convention was thus pioneering; its attempt to define protections in the Gl area was without many models. This fact in and of itself should render the Inter-American Convention an important development in Gl protection, but this has not been the case.

It would be an understatement to say that the Inter-American Convention is neglected in the literature on Gls. In fact, no commentator on Gls has even mentioned this agreement. The numerous scholars and commentators who write about Gl protection commonly recount the history of such protection and yet routinely fail to include the Inter-American Convention in the timeline of the development of this area of law. ${ }_{15}$ Bernard O'Connor's book on GI protection neglects to even mention this convention. ${ }_{16}$ It includes in its coverage the Paris Convention, the two 1891 Madrid Agreements, the Stresa Convention, the Lisbon Agreement, WIPO's draft treaty and model laws, the international wine organisation, the TRIPS Agreement, and five bilateral and two plurilateral agreements on Gls. The Inter-American Convention is not even included in a footnote in the section on protections in the United States. Similarly, Michael Blakeney's recent book on Gl protection fails to mention the Inter-American Convention.17 This book covers all of the same agreements and mentions several additional bilateral agreements, but not the Inter-American Convention. The convention thus seems to have been forgotten by the scholarly community.

One wonders whether the European Union is aware of this convention and its chapter on Gl protection. If it were, one would imagine that the European Union would take better advantage of the existence of the United States' continuing obligations to protect Gls in its negotiation of the TRIPS Agreement and the Transatlantic Trade and Investment Partnership. These are not the only negotiations that have failed to note the Inter-American Convention. Even more curious, this convention has not been identified by

\footnotetext{
11 Loi du 1er Août 1905 sur les Fraudes et Falsifications en Matière de Produits ou de Services (5 Août 1905) Journal Officiel 4813 . This law broadly protected origin labelling, preventing any fraud or misidentification of foodstuffs or agricultural products.

12 Loi du 5 août 1908 Modification de l'Article 11 de la Loi du 1 Août 1905 et Completant Cette Loi par Un Article Additionnel (11 Août 1908) Journal Officiel 5637.

13 Loi du 6 Mai 1919 Relative à la Protection des Appellations d'Origine (8 Mai 1919) Journal Officiel 4726. See also Dev Gangjee, Relocating the Law of Geographical Indications (Cambridge: Cambridge University Press, 2012), pp.83, 102. (The Law of 1919 not only created a more "elaborate" formula for determining origin, but it also shifted the power to make these determinations to the judiciary.)

14 Décret du 16 Juillet 1947 Fixant La Composition du Comite National des Appellations D'origine (19 Juillet 1947) Journal Officiel 6948. Judicial decisions produced uncertainty, so the French government created an official body to both establish and protect appellations of origin. This new regime recognised the importance of both origin and quality. Gangjee, Relocating the Law of Geographical Indications (2012), p.109.

15 e.g. Addor and Grazioli, "Geographical Indications beyond Wines and Spirits" (2002) 5 J. World Intell. Prop. 865, 869; Melkonian, "The History and Future of Geographical Indications in Europe and the United States", available at http://dash.harvard.edu/handle/1/8852204 [Accessed October 22, 2014]; WIPO, "Geographical Indications", 2001; Tellier, "Unfair Competition in Use of Geographical Tradename by Persons Carrying on Business Elsewhere" (1948) 174 A.L.R. 496.

16 Bernard O'Connor, The Law of Geographical Indications (London: Cameron May Ltd, 2004).

17 Michael Blakeney, The Protection of Geographical Indications: Law and Practice (Cheltenham: Edward Elgar Publishing, 2014).
}

54 The WIPO Journal

(2014) 6 W.I.P.O.J., Issue 1 @ 2014 Thomson Reuters (Professional) UK Limited and Contributors 
parties to free trade agreements where both parties are contracting members of the Inter-American Convention. Colombia, Guatemala, Honduras, Nicaragua, Panama and Peru have each negotiated free trade agreements with the United States. Even though numerous other existing agreements are indicated, the Inter-American Convention has not ever been identified. 18

Private parties have also failed to take advantage of the Inter-American Convention in the United States. There have been only a small number of cases litigated in the United States that have relied upon the convention. Only a couple of these have involved a Gl. ${ }_{19}$ The convention may be better utilised in other Contracting States.

\section{The reason for the Inter-American Convention}

The historical context of the convention helps explain some of its unusual features such as strong GI protections. The convention was not only an early attempt at a plurilateral agreement on trademark rights; it was also an outgrowth of the Pan American conferences.

The 1929 convention was one of the results of a 40-year-long effort to create a Pan American Union, which was meant primarily to be a trade union in the Americas. The convention was also a by-product of the Pan Americanism movement that existed in the United States at the time whose objectives included replacing Europe as the dominant power in the region, using institutionalism as alternative to US expansionism and military interventions, and cultivating Latin America as a market for US manufactured goods.20 The ambitions of the union included the creation of a common customs union, railway system and currency, among other things.

The 1929 convention, in particular, was the culmination of efforts dating back to 1889 to harmonise trademark protection in the Americas. There had been six Pan American conventions dealing with trademarks that preceded the 1929 convention, but those conventions proved to be substantively deficient and had limited ratifications.21 The first Pan American Convention was initially negotiated in the shadow of the Paris Convention. Perhaps one reason for the interest in concluding regional agreements on intellectual property was that the large majority of Latin American states were not then members of the Paris Union.22

The 1929 convention included 19 signatory countries.23 The convention entered into force on April 2, 1930.24 Ten states ultimately ratified the convention: Colombia, Cuba, Guatemala, Haiti, Honduras, Nicaragua, Panama, Paraguay, Peru and the United States. The convention remains in force today in each of these countries.25

18 United States-Colombia Trade Promotion Agreement 2011 art.16.3; United States-Panama Free Trade Agreement 2007 art.15.3; United States-Peru Trade Promotion Agreement 2006 art.16.3.

19 Havana Club Holding S.A. v Galleon S.A. 974 F. Supp. 302 (SDNY 1997); Corporation Cimex, S.A. v DM Enterprises \& Distributors Inc., Opposition No.91178943 (November 17, 2008) (not precedential).

20 José Martí, the Cuban nationalist, attended the 1889 Congress as a journalist. He reported that the US only invited the other American nations to join a union because it was "glutted with unsaleable merchandise and determined to extend its dominions in America". José Martí, "On: The Pan-American Congress" La Nación, December 19-20, 1889, available at $h$ ttp://www.christusrex.org/www2/fcf/martipanamerican103197.html [Accessed October 22, 2014].

21 The six conventions were ratified in 1889, 1902, 1906, 1910, 1923 and, finally, 1929.

22 Only Brazil, Cuba and Mexico became members of the Paris Union by 1929. Brazil was a founding member of the Paris Convention in 1883 , and Mexico and Cuba ratified in 1903 and 1904, respectively. The United States ratified the Paris Convention in 1887. A few other Latin American states were original signatories to the Paris Convention only to denounce it shortly after. For instance, the Dominican Republic ratified in 1884, but denounced in 1888. Likewise, Guatemala acceded in 1884, but denounced in 1894. Ecuador acceded in 1884, but denounced the next year. Ladas, Patents, Trademarks, and Related Rights (1975), pp.66, 1745, fn.1 (1975). During the 1929 Pan American Conference it was stated that Brazil and Cuba intended to withdraw from the Paris Convention. Pan American Trademark Conference, "Minutes of the Plenary Sessions and of the Committees of the Conferences", February 11-20, 1929, p.5. Brazil, Cuba and Mexico were also members of the Madrid Agreement of 1891. In 1906 Argentina invited the United States Trademark Association (USTA) to comment on its domestic trademark law. Similarly, in 1908, Ecuador asked the USTA to propose a trademark law which was to become the model for other Latin American countries. International Trademark Association, "About INTA History", available at: www.inta.org/history/pages/history.aspx [Accessed October 22, 2014].

23 The signatories to the convention were Bolivia, Brazil, Chile, Colombia, Costa Rica, Cuba, the Dominican Republic, Ecuador, Guatemala, Haiti, Honduras, Mexico, Nicaragua, Panama, Paraguay, Peru, the United States, Uruguay and Venezuela.

24 The convention became effective in the United States, by Presidential proclamation, on February 27, 1931.

25 See WIPO, "Contracting Parties/Signatories: General Inter-American Convention for Trade-Mark and Commercial Protection", available at http: //www.wipo.int/wipolex/en/other_treaties/parties.jsp?treaty_id=353\&group_id=21 [Accessed October 22, 2014].

The Protection of Geographical Indications in the Inter-American Convention 55

(2014) 6 W.I.P.O.J., Issue 1 @ 2014 Thomson Reuters (Professional) UK Limited and Contributors 


\section{The inclusion of GI protection in the Inter-American Convention}

It is not immediately clear why a chapter on the "Repression of False Indications of Geographical Origin or Source" was included in the Pan-American Convention in 1929. None of the previous Pan American conventions had ever included Gl protections before.26 The 1929 convention not only was the first to address Gl protection, but it devoted an entire chapter to those protections. This convention was also the first to introduce specific protections against unfair competition. The preamble of the convention states that the Contracting States were "animated by the desire to reconcile the different juridical systems which prevail in the several American Republics" and resolved to negotiate the convention "for the protection of trade marks, trade names, and for the repression of unfair competition and false indications of geographical origin". The text of the agreement supports this statement.

The final adoption of the Pan-American Convention occurred on February 20, 1929, in Washington, DC. I have conducted extensive research to determine the origins of the text which ultimately became the final text of the agreement because many of its provisions are so curious.

As a result of a resolution made by the conference held in Havana in 1928, a special committee of the governing board of the Pan American Union consisting of three Latin American representatives was appointed to draft a text for the delegates to consider at its scheduled meeting in Washington the following year.27 That draft text was preoccupied with creating a registration-based system for the Americas as an alternative to the Madrid Arrangement. This draft did not contain any provisions for the protection of Gls.

That draft text, however, was abandoned when the conference met on February 11, 1929.28 Just prior to the conference, Stephen P. Ladas, a respected US trademark practitioner published an influential book in an effort to "facilitate the work of the conference of trade mark experts and specialists of the American countries, meeting at Washington, February 11, 1929".29 In the book, Ladas critiqued the proposed draft as inadequate and offered his own draft text for the Treaty. In a footnote in another book he later published, Ladas mentioned "preparatory work" by US trademark experts-including him-that seems to have been the genesis of his draft. ${ }_{30}$ Ladas's draft was radically different from the committee's draft. It was also the first time Gls were mentioned in any Pan American treaty or draft. Thus, it seems clear that the inclusion of GI protection was the result of the interest of the US delegates, not the Latin American delegates.

Ladas devoted his art.10 to the protection of "indications of the place of origin". In his draft, however, protection was limited to "false indication[s] of origin calculated to deceive the public". ${ }_{31}$ Ladas notes that his draft text embodies proposals made by the Cuban and US delegations at the Conference of The Hague and also incorporates art.1 of the 1891 Madrid Arrangement. Thus, his draft went beyond the Paris Convention in its protection of Gls. Additionally, Ladas not only included an article modelled on the then three-year-old art.10bis of the Paris Convention, but he also proposed a model law of unfair competition in addition to the draft treaty. This model law was based on a draft model law previously prepared by Edward S. Rogers who coincidentally was then serving as one of the three US delegates to the Pan American Conference.

However, neither the committee's draft nor Ladas's draft ended up serving as the basis for the conference

26 The 1910 Convention (art.8) and 1923 Convention (art.V) did include references to false representation of origin, but it was not clear that this was meant in the geographic sense.

27 A proposed draft was thus prepared by the Ambassador of Cuba and ministers from Ecuador and Uruguay and was submitted to the conference on November 23, 1928. Pan American Trademark Conference, "Preparatory Data for the Pan American Trade Mark Conference: Report of the Committee of the Governing Board of the Pan American Union", February 11, 1929.

28 Stephen P. Ladas, Patents, Trademarks, and Related Rights: National and International Protection (Cambridge, MA: Harvard University Press, 1975), pp.1754-1756, fn.40 (suggesting that the draft predominantly reflected the results of "preparatory work" undertaken by New York trademark experts).

29 Stephen P. Ladas, The International Protection of Trade Marks by the American Republics (Cambridge, MA: Harvard University Press, 1929).

30 Ladas, Patents, Trademarks, and Related Rights (1975), p.1754, fn.40.

31 Ladas, Patents, Trademarks, and Related Rights (1975), pp.69-70.

56 The WIPO Journal

(2014) 6 W.I.P.O.J., Issue 1 @ 2014 Thomson Reuters (Professional) UK Limited and Contributors 
negotiations. Instead, on the first day of the meeting, the delegate from Cuba proposed substituting the committee's draft with a completely different draft ostensibly prepared by the Cuban delegation "[f[or the purpose of expediting the work" of the conference. ${ }_{32}$ This new draft was clearly based on Ladas's draft, not the initial committee's draft. Ladas later acknowledged that this draft was "prepared with the cooperation of the United States delegation". 33

The conference then agreed to appoint four committees to carry out the work of the conference. Remarkably, one committee was devoted to "Unfair Competition and False Indication of Origin". A second was a "drafting committee" comprised of only four delegates; one representing each of the four languages spoken by the delegates. 34 Edward Rogers was appointed to this committee to represent the English language. ${ }_{35} \mathrm{He}$ was one of the foremost experts in both US and international trademark law at the time.

I recount this history in detail because where the chapter on Gl protection came from is key to understanding its significance. While it might be assumed that such protection was included at the insistence of the Latin American delegates who in their civil law traditions may have had laws more in line with European states, there is no evidence that this is true. It does not appear that any of the Latin American countries who were represented had themselves any previous experience with Gl protection. Rather, it appears that these protections came at the insistence of the US delegation. First, these protections follow a common law tradition and are rooted in unfair competition. 36 Secondly, at the time of the negotiation, there was concern on behalf of US manufacturers that goods were being sold as American-made in Latin America. It may have been for these reasons that this protection was included. It may also have been an opportunity to codify US common law on this topic, as was the case with the chapter on protections against unfair competition.

After the convention was finalised but before it was ratified, the US delegation produced a document entitled "The Advantages Accruing to American Citizens from the General Convention for Trademark and Commercial Protection". The US delegation highlights the protections for Gls in that document:

"Chapter V extends through Latin America common law principles of honest trading which have been enforced in the United States for forty years under the elastic jurisdiction of our equity courts. It has always been the law in this country that the application of geographical terms to merchandise not originating in the geographical district indicated, is unfair and unlawful. This chapter extends that salutary doctrine throughout Latin America. It is of value because it enables persons whose goods originate in famous districts to secure to themselves the advantage which announcement of that source conveys, and prevents others not entitled to use the geographical indication because not operating in the district from taking unfair advantage by the false application to their goods of the geographical name. Concretely, if American-made goods acquire a reputation in Latin America, this chapter will prevent goods originating elsewhere from masquerading directly or indirectly as American-made."

\section{The contribution of the Inter-American Convention to the protection of Gls}

Given the dearth of specific protection of Gls in international law and the absence of codified protection in US law, the breadth and depth of the protections in the convention is unexpected. The chapter on Gls begins with art.23, which provides:

\footnotetext{
32 Pan American Trademark Conference, "Minutes of the Plenary Sessions and of the Committees of the Conferences", 1929, p.4. 33 Ladas, Patents, Trademarks, and Related Rights (1975), p.1755.

34 Pan American Trade Mark Conference, "Pan American Trade Mark Conference, Washington DC—Pan American Trade Mark Conference Opens Sessions", February 11, 1929, p.2 (press release).

35 Pan American Trademark Conference, "Minutes of the Plenary Sessions and of the Committees of the Conferences", 1929, p.3.

36 Harry D. Nims, The Law of Unfair Business Competition Including Chapters on Trade Secrets and Confidential Business Relations; Unfair Interference with Contracts; Libel and Slander of Articles of Merchandise, Trade Names, and Business Credit and Reputation (New York: Baker, Voorhis, 1909), p.260 ("The [trade name] cases here considered, relate to names of goods which are not capable of exclusive appropriation, but which are protected against general use, by the law of unfair competition.").
}

The Protection of Geographical Indications in the Inter-American Convention 57 (2014) 6 W.I.P.O.J., Issue 1 @ 2014 Thomson Reuters (Professional) UK Limited and Contributors 
"Every indication of geographical origin or source which does not actually correspond to the place in which the article, product or merchandise was fabricated, manufactured, produced or harvested, shall be considered fraudulent and illegal, and therefore prohibited."

The convention uses the phrase "indication of geographical origin or source". In the draft of the convention that was presented to the conference, as with Ladas's draft, the phrase used was "indication of source or origin"; "geographical" was added by the drafting committee at the suggestion of Edward Rogers.37

This provision appears more similar to art.23 than art.22 of the TRIPS Agreement, yet it applies to all goods. The language would appear to prohibit the use of geographical names that are false, yet not misleading. In his commentary on his draft, Ladas referred to the then existing protection in the Paris Convention as a protection against "qualified fraud", in contrast to the "unqualified" protection in the Madrid Arrangement. 38 The Ladas draft clearly conditioned protection on uses that were misleading, but this formulation appears to have been abandoned in the final text.

Moreover, it does not appear from this article that the falsehood need be believable or material to be actionable. Thus, arbitrary uses of geographic names appear to be prohibited. Subsequent articles offer some qualifications of the broad protection suggested by this article.

Article 24 provides:

"For the purposes of this Convention the place of geographical origin or source shall be considered as indicated when the geographical name of a definite locality, region, country or nation, either expressly and directly, or indirectly, appears on any trade mark, label, cover, packing or wrapping, of any article, product or merchandise, directly or indirectly thereon, provided that said geographical name serves as a basis for or is the dominant element of the sentences, words or expressions used."

In the conference, Rogers stated that this article deals only with cases of deception and should be drafted to clearly indicate this limitation. 39 The last phrase of this article was added by Rogers to make this point.

His original formulation was as follows: "provided that said geographical name serves as a basis or motive for the sentences, words or expressions employed". 40 Article 24 also makes clear that Gls are protected even when used indirectly, that is, not just when used in trademarks, but in other areas of the label or packaging. An indirect reference to a geographical origin could be graphic, and it thus appears that such a use would be covered.

Article 25 provides:

"Geographical names indicating geographical origin or source are not susceptible of individual appropriation, and may be freely used to indicate the origin or source of the products or merchandise or his commercial domicile, by any manufacturer, industrialist, merchant or agriculturist established in the place indicated or dealing in the products there originating."

Article 25 thus states a basic principle under US trademark law: that geographical names are not subject to individual appropriation. By the time this article was drafted, however, an exception had emerged under unfair competition law where a geographic name that has acquired secondary meaning and use by competitors would result in confusion as to the source's origin.41 Without this exception, this provision would appear to drastically limit trademark rights.

37 Pan American Trademark Conference, "Minutes of the Plenary Sessions and of the Committees of the Conferences", 1929, p.62.

38 Ladas, The International Protection of Trade Marks by the American Republics (1929), p.69.

39 Pan American Trademark Conference, "Minutes of the Plenary Sessions and of the Committees of the Conferences", 1929, p.87.

40 Pan American Trademark Conference, "Minutes of the Plenary Sessions and of the Committees of the Conferences", 1929, p.87.

${ }_{41}$ Finchley Inc v Finchley Co 40 F.2d 736 (DC MD 1929) ("The rule would apply even as against those doing business within the same geographical limits if the name was used fraudulently for the purpose of misleading buyers as the actual origin of the thing produced, or palming off the products of one person as those of another."); Elgin National Watch Co v Loveland 132 F. 41 (CC lowa 1904) (enjoining the use of Elgin by the Elgin Jewellery Company even though the defendant maintained a one-room place of business in Elgin, Illinois, which was the home of the reputed Elgin National Watch Company); Waltham Watch Co v United States Watch Co 173 Mass. 85 (1899).

58 The WIPO Journal

(2014) 6 W.I.P.O.J., Issue 1 @ 2014 Thomson Reuters (Professional) UK Limited and Contributors 
Article 26 provides:

"The indication of the place of geographical origin or source, affixed to or stamped upon the product or merchandise, must correspond exactly to the place in which the product or merchandise has been fabricated, manufactured or harvested."

Article 26 demands exactitude when indicating a geographical place of origin. If a good is from a nearby place, it may not employ the geographic name. This issue had been the subject of litigation in the United States.42

Article 27, without using the word "generic", appears to provide an exemption for generic names:

"Names, phrases or words, constituting in whole or in part geographical terms which through constant, general and reputable use in commerce have come to form the name or designation itself of the article, product or merchandise to which they are applied, are exempt from the provisions of the preceding articles; this exception, however, does not include regional indications of origin of industrial or agricultural products the quality and reputation of which to the consuming public depend on the place of production or origin."

Notice, however, that there is an exception to the exception in the last section of the article for regional terms that have a reputation for quality.

Article 28 openly addresses remedies and appears to resolve the persistent criticism of the Paris Convention that the unfair competition provisions in art.10bis had no teeth. It states that in the absence of special remedies for false indications of geographical origin in domestic law, trademark law remedies will apply:

"In the absence of any special remedies insuring the repression of false indications of geographical origin or source, remedies provided by the domestic sanitary laws, laws dealing with misbranding and the laws relating to trade marks or trade names, shall be applicable in the Contracting States."

There is no mention of products of the vine as in the Madrid Agreement, or vineyard products as in the draft considered by the conference, or of any other category of goods that would be subject to heightened protections.43 There also does not seem to be any language that either extends or denies protection to services.

\section{Unfair competition in the Inter-American Convention}

In addition to having a chapter on GI protection, the Inter-American Convention also includes a chapter on unfair competition. Chapter IV of the convention is titled "Repression of Unfair Competition" and sets out detailed protections against acts of unfair competition that go well beyond the then existing protection in the statutory law in any of the member states or any international convention. That chapter mentions the protection of Gls as an aspect of unfair competition in a manner far more direct than the current language of art.10bis of the Paris Convention.44

This chapter details specific acts that are "declared to be acts of unfair competition" including

\footnotetext{
42 Dunbar $v$ Glenn 42 Wis. 118 (1877) (restraining the defendant from selling, or offering for sale, any mineral water represented as being "Bethesda mineral water", notwithstanding such water was taken from a spring only 1,200 feet from the test spring and was of the same chemical analysis as the water of the Bethesda spring).

43 The draft convention also mentioned tobacco products. Ladas's draft did not mention any particular kinds of products. The references to wine and tobacco were eliminated at the suggestion of Rogers. Pan American Trademark Conference, "Minutes of the Plenary Sessions and of the Committees of the Conferences", 1929, p.88.

44 See also Nims, The Law of Unfair Business Competition Including Chapters on Trade Secrets and Confidential Business Relations; Unfair Interference with Contracts; Libel and Slander of Articles of Merchandise, Trade Names, and Business Credit and Reputation (1909). The inclusion of GI protection under the umbrella of unfair competition may further suggest that US delegates were involved in the making of this draft, given the historical development of GI protection in the United States, which drew upon unfair competition.
}

The Protection of Geographical Indications in the Inter-American Convention 59

(2014) 6 W.I.P.O.J., Issue 1 @ 2014 Thomson Reuters (Professional) UK Limited and Contributors 
"[t]he use of false indications of geographical origin or source of goods, by words, symbols, or other means which tend in that respect to deceive the public in the country in which these acts occur" (art.21.c).

Additionally, art.21.d describes another act of unfair competition:

"To sell, or offer for sale to the public an article, product or merchandise of such form or appearance that even though it does not bear directly or indirectly an indication of origin or source, gives or produces, either by pictures, ornaments, or language employed in the text, the impression of being a product, article or commodity originating, manufactured or produced in one of the other Contracting States."

Thus, two of the four enumerated acts contrary to principles of unfair competition explicitly deal with geographical origin.

Finally, the convention singles out trade names as another category of protection. The protection of trade names under US law at this time is significant to the protection of Gls because, during this period, US courts commonly referred to Gls as "trade names". At the time, a trade name was a designation that was not susceptible of exclusive appropriation, but yet had acquired secondary meaning and was employed by a merchant as a means of identifying its product, business or service.45 Thus, trade names frequently involved the name of the place where the business was located.

\section{The continuing significance of the Inter-American Convention}

This agreement would be noteworthy even if it had since been denounced by the United States and the other Member States. Had it been denounced, it would be noteworthy because strong geographical protections had been proposed by and acceded to by the United States, indicating that these protections were consistent with US trademark law. However, it is not the case that this treaty has been denounced; this treaty is still in force in all of the original 10 Member States, including the United States.

The Inter-American Convention is therefore not a mere historical relic or curiosity. Instead, it is operable law in 10 countries. The Inter-American Convention is self-executing, meaning that these rights are immediately operative in US courts; the legislature does not need to act in order to make the treaty operative. Sometimes treaties contain language indicating that they are not self-executing. There is no language in the Inter-American Convention suggesting that it is not self-executing. In addition, in most cases, the rights are so specific and detailed that legislative implementation is unnecessary.

The US Supreme Court has held that the Inter-American Convention is a self-executing treaty, and thus became law in the United States without the necessity for implementing legislation: "This treaty on ratification became a part of our law. No special legislation in the United States was necessary to make it effective." ${ }_{6}$ Coincidentally, Edward Rogers, the US delegate to the Pan American Conference, represented the petitioner who successfully asserted a claim under the Inter-American Convention in the Supreme Court case.47

The participation of Rogers in the drafting and negotiation of this convention is also a reason for its continued significance. In order to understand the reasoning behind the inclusion of a chapter on the "Repression of False Indications of Geographical Origin or Source" within the Inter-American Convention in 1929 and the absence of development and regulation of Gls under the Lanham Act in 1946, we must understand Rogers' contributions. His academic work, together with his direct participation in the drafting of the Lanham Act and international agreements, are the keys to this mystery.

\footnotetext{
45 Tellier, "Unfair Competition in Use of Geographical Tradename by Persons Carrying on Business Elsewhere" (1948) 174 A.L.R. 496.

46 Bacardi v Domench 311 U.S. 150, 162-163 (1940).

47 In the petitioner's brief, he stated: "No special legislation implementing this treaty is necessary in the United States" (p.26).
}

60 The WIPO Journal

(2014) 6 W.I.P.O.J., Issue 1 @ 2014 Thomson Reuters (Professional) UK Limited and Contributors 
Rogers had become one of the few specialists in trademark law in the United States prior to World War I. ${ }_{48} \mathrm{He}$ was called "the Dean of the Trademark Bar" ${ }_{49}$ during his lifetime, and he was so well regarded in US trademark law that, when he died, the Trademark Reporter devoted an entire (200-page) book to his legacy. Rogers is credited with major drafts of the Lanham Act and has since been referred to as the "father of the Lanham Act and perhaps the greatest trademark scholar and lawyer in the first half of the $20^{\text {th }}$ century". .50 As he was a distinguished and well-respected trademark practitioner in the United States, Rogers was able to bring to the negotiating table a deep and sophisticated understanding of US trademark law. Moreover, he would also have been able to bring to the drafting of the Lanham Act a deep and sophisticated understanding of the provisions of the Inter-American Convention and their applicability in US courts as a self-executing treaty.

Rogers was fairly preoccupied with the topic of unfair competition law. He wrote one book $_{51}$ and eight law review articles on the subject, 52 as well as a book review, ${ }_{53}$ a book foreword, ${ }_{54}$ and a published speech. ${ }_{55} \mathrm{He}$ also drafted a "Uniform Code dealing with Unfair Competition", which was an effort to distil the rules from US common law and to incorporate international developments of enumerated acts of unfair competition. This work became the basis of the chapter on unfair competition in the Inter-American Convention. Rogers understood Gl protection as coming under the umbrella of unfair competition.

The unfair competition law that had developed in the United States prior to the convention had no difficulty in enjoining competitors' false use of geographical terms. But these cases usually involved the following elements: (1) a geographic name with a developed reputation; (2) a false use of the place name; (3) a commercial injury to a competitor (diversion of sales and/or harm to reputation); and (4) a fraud on public.

A few untidy developments occurred in the doctrine, however. First, some cases allowed the false use of geographic term where the goods were clearly labelled with actual geographic origin. ${ }_{56}$ Secondly, most of these cases involved plaintiffs who were themselves using the geographical term as a mark or a trade name and had been responsible for cultivating the reputation of the word. In fact, a few cases actually denied relief in cases where the plaintiffs could not show that they had developed trademark or trade name rights in the geographic word.57

As Rogers knew well, the United States had protected Gls as early as 1870 through common law unfair competition principles. Yet he also knew, and as these cases themselves made clear, the US history of protecting geographical names is complicated and difficult to codify.

48 Keith M. Stolte, "A Response to Jerome Gilson's Call for an Overhaul of the Lanham Act” (2004) 94 Trademark Rep. $1335,1346-1348$.

49 Julius R. Lunsford Jr, "Foreword" (1972) 62 Trademark Rep iv.

50 Miles J. Alexander, "100th Anniversary Issue: Reflections of Former Editors-in-Chief" (2011) 101 Trademark Rep. 9, 9-10.

51 Edward S. Rogers, Good-Will Trade-Marks and Unfair Trading (Chicago: A.W. Shaw Company, 1914).

52 Edward S. Rogers, "Comments on the Modern Law of Unfair Trade" (1909) 3 III. L. Rev. 551; Edward S. Rogers, "Doctrine of Unfair Trade" (1909) 7 Mich. L. Rev. 409; Edward S. Rogers, "Predatory Price Cutting as Unfair Trade" (1913) 27 Harv. L. Rev. 139; Edward S. Rogers, "Unfair Competition" (1919) 17 Mich. L. Rev. 490; Edward S. Rogers, "Business Good-Will and Trade-Marks Nationally and Internationally Considered" (1939) 34 Trademark Rep. Bull. 281; Edward S. Rogers, "New Directions in the Law of Unfair Competition" (1940) 74 N.Y. L. Rev. 317 (1940); Edward S. Rogers, "Unfair Competition" (1945) 35 Trademark Rep. 126; Edward S. Rogers, "New Concepts of Unfair Competition under the Lanham Act" (1948) 38 Trademark Rep. 259.

53 Rogers, "New Concepts of Unfair Competition under the Lanham Act" (1948) 38 Trademark Rep. 259.

54 Walter J. Derenberg, Trade-Mark Protection and Unfair Trading (Albany: Matthew Bender and Co, 1936).

55 Edward S. Rogers, "The Legal Side of Fair Trade", Speech at the Annual Meeting of Association of National Advertisers Inc, 1937.

56 At least one court still enjoins this use.

57 New York \& R Cement Co v Coplay Cement Co 44 F. 277 (CC Pa 1890) (allowing the defendant to use the denomination "Rosendale Cement" for cement not manufactured in Rosendale or from the stone procured at Rosendale because the plaintiff did not have the exclusive right to use that place name); California Apparel Creators v Wieder of California Inc 162 F.2d 893 (2nd Cir. 1947) (allowing New York apparel manufacturers to continue to use the words "California" and "Californian" even though an Incorporated Trade Association and 75 of its members argued that they would be injured by such use).

The Protection of Geographical Indications in the Inter-American Convention 61

(2014) 6 W.I.P.O.J., Issue 1 @ 2014 Thomson Reuters (Professional) UK Limited and Contributors 


\section{Conclusion}

Conventional wisdom holds that the United States' main role in the development of protection for Gls has been to oppose new protections. But there is one significant fact that contradicts this story: In 1929 the United States ratified a plurilateral trademark convention that contained a chapter affording significant protections for Gls. Furthermore, it appears that the United States played a major role in drafting that chapter. Moreover, the protections contained in that chapter went well beyond any existing protections.

It is a shame that the Inter-American Convention and its chapter on GI protection has been forgotten by the international community. A stronger understanding of the US history of protecting Gls and its existing international commitments should aid trading partners in the current discussions of the competing approaches of the United States and the European Union. What this history demonstrates is that the United States has not historically been opposed to the protection of Gls and in fact has a long history of such protection. The existence of the Inter-American Convention and the legal developments that it enshrines could enrich the discussion of the available avenues for protecting Gls today. 